\title{
PARTIE ETNICZNE W REPUBLICE CZESKIEJ
}

\section{ETHNIC PARTIES IN THE CZECH REPUBLIC}

\section{abstract}

While analyzing the Czech politics, especially the party system after the collapse of the communist system, we notice a conspicuous presence of ethnic parties. In the political landscape, we have Moravian parties which highlight the political significance of the north-eastern region of the Czech Republic as well as a multiethnic party called Coexistentia. Parties of the Roma minority can also be included in this category. Popular support for ethnic groupings and their political role were much more pronounced in the early 1990s, which was linked with an increase in tensions in the society caused by the effects of political and economic transformation. This article examines the practical functioning of these parties as well as indicates the reasons for their appearance and for the withdrawal of the ethnic issue from this plane of representation. It also contains general theoretical assumptions concerning the cleavages and ethnic parties.

Key words: ethnically based parties; Czech Republic; Moravian identity

MARTYNA WASIUTA Uniwersytet Kardynała Stefana Wyszyńskiego Warszawa

Na podstawie obserwacji czeskiego życia politycznego, szczególnie systemu partyjnego, po upadku systemu komunistycznego możemy wykazać obecność partii etnicznych w Republice Czeskiej. Mieliśmy do czynienia z partiami morawskimi, nawiązującymi do politycznego znaczenia północno-wschodniego regionu Republiki Czeskiej i partią wieloetniczną Coexi-

CITATION: Wasiuta, M. (2017) Partie etniczne w Republice Czeskiej. Sprawy Narodowościowe. Seria nowa, 2017(49). https://doi.org/10.11649/sn.1244

This work was supported by the author's own resources. No competing interests have been declared.

This is an Open Access article distributed under the terms of the Creative Commons Attribution 3.0 PL License (creativecommons.org/licenses/by/3.0/pl/), which permits redistribution, commercial and non-commercial, provided that the article is properly cited. (C) The Author(s) 2017.

Publisher: Institute of Slavic Studies, Polish Academy of Sciences 
stentia. Do tego grona aspirowały także partie mniejszości romskiej. Poparcie dla tych ugrupowań oraz ich polityczna rola były zdecydowanie większe na początku lat 90 . XX wieku, co wiązało się ze wzrostem napięcia w społeczeństwie wywołanym skutkami transformacji politycznej i gospodarczej. Niniejszy artykuł odpowiada na pytania dotyczące praktyki funkcjonowania tych partii oraz wskazuje na przyczyny ich pojawienia się i wycofania się kwestii etnicznej z tej płaszczyzny reprezentacji. W tekście zawarte zostały również główne założenia teoretyczne dotyczące rozłamów socjopolitycznych i partii etnicznych.

Słowa kluczowe: partie etniczne; Republika Czeska; tożsamość morawska

\section{WSTĘP}

$\mathrm{N}$ iniejszy artykuł stanowi próbę odpowiedzi na pytania o praktykę funkcjonowania partii etnicznych w Europie Środkowej i Wschodniej na przykładzie Republiki Czeskiej. Sprawdzone zostanie, czy takie podmioty rzeczywiście istnieją bądź zaistniały w czeskim systemie politycznym i które z nich można określić mianem partii etnicznych. Podjęta zostanie również próba wskazania przyczyn ich pojawienia się oraz zaniku w czeskim systemie partyjnym, ich elektoratów, specyfiki tychże ugrupowań, a także ich osiągnięć politycznych. Przedtem jednak warto poczynić ogólne rozważania teoretyczne, które wskażą, czym są partie etniczne i czym różnią się od klasycznych partii politycznych; czy stanowią zupełnie inną rodzinę, czy też można je rozpatrywać jako należące do istniejących już typologii.

Obecnie w polskiej literaturze politologicznej brak opracowania traktującego o czeskich partiach etnicznych. Tematyka ta została podjęta tylko częściowo przez polskich badaczy przy okazji publikacji o czeskim systemie partyjnym. Szczegółowo zaś została uwzględniona przez czeskich politologów, zwłaszcza z Uniwersytetu Masaryka w Brnie. Niniejszy tekst ma się przyczynić do wypełnienia luki w polskich badaniach nad czeską polityką.

Historia czeskiego systemu partyjnego po 1989 r. pokazuje, że mamy do czynienia z partiami etnicznymi/regionalnymi (Strmiska, 2003, s. 3), takimi jak partie morawskie: Ruch na rzecz Demokracji Samorządowej - Stowarzyszenie dla Moraw i Śląska czy Czesko-Morawska Unia Centrum (Wojtas, 2011, ss. 106-106), które podnoszą kwestie nierówności mieszkańców czeskiego Śląska i Moraw z ludnością Czech i Słowacji (Kowalczyk, Tomczak, 2007, s. 185), ale też partiami mniejszości etnicznych i narodowych: partie romskie - Romska Inicjatywa Obywatelska (Romská občanská iniciativa - ROI), Ruch Zaangażowanych Romów (Hnutí angažovaných Romư), Romski Kongres Narodowy (Romský národní kongres), Partia Obywateli Narodowości Romskiej Północnoczeskiego Kraju (Strana občanů romské národnosti Severočeského kraje), Czeskie Narodowe i Romskie Ruchy Polityczne, Chrześcijańsko-Demokratyczna Partia Romów (České národnostní a romské politické hnutí České republiky, Křestanská a demokratická strana Romü), partie wieloetniczne - Wspólnota - Soužití - Együttélés - Spolužitie (COEX). Obecnie partie etniczne w Republice Czeskiej pełnią rolę marginalną (Mareš, 2003, s. 2). Ich znaczenie było większe w przeszłości, w okresie transformacji postkomunistycznej, czego przykładem jest wspomniana Wspólnota, Ruch na rzecz Demokracji Samorządowej - Stowarzyszenie dla Moraw i Śląska, które posiadały swoje reprezentacje w parlamencie (Kowalczyk, Tomczak, 2007, s. 185). 
Partie etniczne w polskich badaniach politologicznych nie cieszą się obecnie dużym zainteresowaniem. Deficyt tych badań dostrzega się w wymiarze teoretycznym i praktycznym, a pierwszy z nich jest zdecydowanie bardziej dotkliwy. Badania nad polityką etniczną są bardziej rozwinięte w krajach borykających się z kwestiami etnicznymi (Rotschild, 1981, s. i), stanowiących niegdyś kolonie zamorskie i ich kolonizatorów. W tych krajach dostrzega się bowiem problemy związane z różnorodnością etniczną ich obywateli, co często prowokuje do podejmowania badań w celu ich rozwiązania. Nawet sam termin „etnopolityka" pojawia się po raz pierwszy w językach angielskim i francuskim w 1995 r. (Żelazny, 2004, s. 177).

W przypadku Polski deficyt badań nad partiami etnicznymi wynika najprawdopodobniej z braku głębokich problemów etnicznych. Kraj jest jednolity kulturowo (Koss-Goryszewska, 2010, s. 1), a odsetek obywateli, którzy deklarują przynależność do mniejszości etnicznych wynosi 0,75\% wszystkich mieszkańców Polski (Czwarty raport dotyczący sytuacji mniejszości narodowych i etnicznych oraz języka regionalnego w Rzeczypospolitej Polskiej, 2013, s. 6), rozproszonych zresztą w 13 grupach etnicznych. Henryk Chałupczak i Grzegorz Babiński wskazują też na problem niejasności pojęć i przedmiotu badań nad samą etnicznością w polityce, który jest według nich trudny do precyzyjnego opisu, powodujący niechęć i determinujący w konsekwencji niskie zainteresowanie uporządkowaniem tego obszaru badań (Babiński, 1998, s. 7; Sakson, 2014, s. 13).

Znacznie większe zainteresowanie tematem partii etnicznych obserwujemy wśród zagranicznych badaczy. Na podstawie ich opracowań możliwe jest określenie miejsca tych ugrupowań etnicznych w obszarze badań nad partiami i systemami partyjnymi. Pozwalają one stwierdzić, że partie etniczne nie są typowymi partiami politycznymi. Podejście strukturalne pozwala na określenie ich takim mianem, ponieważ są organizacjami zrzeszającymi członków, posiadającymi swoją strukturę (kierownictwo etc.), dążącymi do objęcia stanowisk w państwie (Herbut, 2002, ss. 28-31). Problem pojawia się wówczas, gdy analizujemy je w perspektywie funkcjonalnej. Okazuje się bowiem, że część badaczy wyklucza je z grona klasycznych partii politycznych, ponieważ partie etniczne ich zdaniem nie agregują interesów, ale podkreślają ich partykularyzm oraz nie integrują społeczeństwa i nie kreują społecznego konsensu (Horovitz, 1985, ss. 296-297). To, co osłabia ich kondycje jako partii politycznych według jednych badaczy, przez innych jest rozpatrywane już na korzyść partii etnicznych sensu stricto. Ich udział w systemie partyjnym pozwala na uwzględnianie interesów podzielonego społeczeństwa, nie wyklucza jego segmentów, przez co pozwala na instytucjonalne skanalizowanie nastrojów etnicznych, oddalając groźbę niekontrolowanego konfliktu (Ishiyama, 2001, s. 28) oraz stanowi przejaw demokratycznego konsocjonalizmu (Touquet, 2011, s. 452). Celem niniejszego opracowanie nie jest rozstrzygnięcie tej kwestii, a jedynie jej zarys, i pozostawia ją otwartą.

\subsection{Definiowanie partii etnicznych}

Do partii etnicznych będących przedmiotem niniejszego opracowania zaliczam podmioty określane w literaturze politologicznej mianem partii etnopolitycznych (ethnopolitical parties), partii mniejszości etnicznych lub narodowych (minority parties) bądź też partii regionalnych (regionalist parties) i etnoregionalnych (ethnoregionalist parties), a także wielo- 
etnicznych (multiethnic parties). Ich wspólnym rdzeniem jest, ogólnie rzecz biorąc, oparta na kryteriach etnicznych (regionalnych) struktura członkowska i kierownictwo, elektorat i typ apelu, z których z kolei wynikają szczególne funkcje, jakie wypełniają one względem grupy etnicznej i jej otoczenia. Partie te bazują na rozłamach socjopolitycznych centrumperyferie (Lipset \& Rokkan, 1967, s. 16) lub na podziale etnoregionalnym (De Winter \& Türsan, 2003, s. 1).

Według politologa Donalda Horovitza partia etniczna jest organizacją polityczną, znajdującą się pomiędzy partią polityczną a grupą interesu (Horovitz, 1985, s. 291). Paul R. Brass opisuje ją jako pewną organizację polityczną dominującą $w$ reprezentowaniu żądań określonej grupy etnicznej, w opozycji do jej rywali (Ishiyama \& Breuning, 2011, s. 225). Według Kanchan Chandry i Davida Metza, partia etniczna to partia otwarcie przedstawiająca się wyborcom jako obrońca interesów jednej grupy etnicznej lub agregatu grup przed wykluczeniem ich przez inną grupę lub grupy, i osadza tę reprezentację w centrum w swojej strategii mobilizacyjnej (Chandra \& Metz, 2002, s. 5). Donna Lee Van Cott zaś proponuje, by partią etniczną nazywać organizację uprawnioną do rywalizacji wyborczej, której większość przywódców i członków identyfikuje się z grupą etniczną niedominującą i której główne hasła programu wyborczego zawierają żądania o charakterze etnicznym i kulturowym (Van Cott, 2005, s. 3). Do cech, na podstawie których klasyfikuje się partie etniczne, należą: wielkość poparcia, które partia otrzymuje w wyborach od danej grupy etnicznej, od której jest uzależniona, oraz to, czy partia przedstawia siebie jako reprezentanta tejże grupy. Partia etniczna jako taka nie byłaby etniczną, gdyby nie otrzymywała większości poparcia od konkretnej grupy etnicznej i nie określała w tych kategoriach samej siebie (zwłaszcza w nazwie partii), wykluczając w ten sposób inne segmenty elektoratu (Ishiyama \& Breuning, 2011, s. 227).

Zauważamy więc, że etniczność rozpatrywanych w niniejszym opracowaniu partii jest cechą ekskluzywną w porównaniu do tradycyjnych partii politycznych, opartych na pozostałych rozłamach politycznych. Partia etniczna nie jest też podmiotem powstałym samoistnie, ale uwarunkowanym istnieniem innych partii, masowych, agregujących interesy większości etnicznej lub innych grup etnicznych, które są odmienne od interesów tych pierwszych bądź przez nie nieuwzględniane w swoich programach.

\subsection{Funkcje partii etnicznych $w$ systemie politycznym}

Oprócz klasycznych funkcji partii politycznych, jakie mogą wypełniać partie etniczne, częściowo zgodnych z paradygmatem funkcjonalnym, wspomniane ugrupowania mogą realizować także inne, wynikające ze swojej specyfiki.

Donald Horovitz pisze, że partia etniczna (ethnically based party) jest narzędziem kreowania konfliktu etnicznego w państwie. Poprzez odwoływanie się do elektoratu w kategoriach etnicznych, wnoszenie etnicznych postulatów wobec rządu oraz poprzez podkreślanie etnicznie szowinistycznych elementów w każdej z grup, partie te tylko pogłębiają i rozszerzają podziały etniczne. Co więcej, pojawianie się partii etnicznych może wywołać reakcję łańcuchową w systemie partyjnym, w postaci przyjęcia podobnych strategii przez pozostałe. Przemiany tego typu często sprawiają, że system partyjny jest nie tylko silnie zantagonizowany, ale sprzeczny z podstawowymi założeniami demokratycznej polityki (Ishiyama \& Breuning, 2011, s. 2). Ugrupowania etniczne służą bowiem interesom jednej grupy, tej która udziela jej największego poparcia. 
Partie etniczne stawiają sobie za główny cel swojej działalności reprezentowanie interesu grupy etnicznej, nie skupiają się na promowaniu apelu skierowanego do innych grup. Początki swojej działalności opierają na metodach grupy nacisku w trosce o przetrwanie kulturowe czy językową autonomię. Początkowo nie dążą do objęcia stanowisk w strukturach władzy, czego jednak też nie wykluczają. Potencjalne zmiany spowodowane są przesunięciem w orientacji celów i pokusą zdobycia władzy, wzrastającą w miarę upływu czasu i tego, jak partia staje się widoczna. Bardziej efektywnym sposobem wpływania na politykę etniczną jest już piastowanie urzędów, zaś uzyskanie i utrzymanie władzy politycznej zobowiązuje do odwoływania się partii do elektoratu spoza zaplecza ściśle etnicznego. Partia etniczna może więc, oprócz wypełniania funkcji grupy interesu, poszerzyć swój apel o inne, ogólnospołeczne i publiczne postulaty. Ich rola może więc być zarówno destruktywna, jak i konstruktywna (Ishiyama \& Breuning, 2011, ss. 7-8).

Partie etniczne poprzez swój udział w polityce państwa pozwalają na reprezentację kolejnych segmentów społeczeństwa, które nie odnajdują jej w programach wyborczych pozostałych partii politycznych. Dopuszczanie ich do współpracy może więc stanowić mechanizm służący redukcji konfliktów etnicznych i przejaw demokracji konsocjalnej (Zenderowski \& Pieńkowski, 2014, s. 168).

\subsection{Typologie partii etnicznych}

Rodzina partii etnicznych nie jest jednolita. Wśród nich można bowiem wyróżnić partie etnoregionalne, wśród których również obserwowane jest zróżnicowanie na partie: umiarkowanego protekcjonizmu, partie autonomistyczne, narodowo-federalistyczne oraz separatystyczne (Ishiyama \& Breuning, 2011, s. 226). Partie typu umiarkowanego protekcjonizmu dążą do zapewnienia niepowtarzalnego charakteru grupy etnicznej, którą reprezentują, działając $w$ ramach istniejącego systemu politycznego (np. Liga Ticino w Szwajcarii, Partia Szwedów w Finlandii). Partie typu autonomicznego dążą do autonomii politycznej reprezentowanej przez siebie grupy i autonomii regionu geograficznego przez nią zamieszkiwanego oraz do odpowiedniego podziału władzy na tym terytorium. Do partii tego typu należą również partie narodowo-federalistyczne, które postulują pewne formy samorządności na danym terytorium, możliwe do osiągnięcia przez transformację państwa unitarnego w federacyjne (np. Liga Północna we Włoszech). Wśród partii czwartego typu wyróżnić można partie separatystyczne niepodległościowe i irredentystyczne. Pierwsze z nich apelują o całkowitą niepodległość regionów przez siebie reprezentowanych, znajdujących się w sferze wpływów ponadnarodowej organizacji politycznej lub poza nią (np. Szkocka Partia Narodowa). Partie podtypu irredentystycznego dążą do oderwania reprezentowanego regionu i przyłączenia go do innego państwa, z którym się bardziej utożsamiają pod względem etno-kulturowym (np. Sinn Fein w Irlandii Północnej) (Ishiyama \& Breuning, 2011, s. 226).

Partie etnoregionalne są przykładem partii monoetnicznych w rozumieniu Floriana Biebera. Obok nich politolog wyróżnit jeszcze partie etniczne z mniejszościowymi kandydatami (ethnic parties with minority candidates), obywatelskie partie wrażliwe etnicznie (diversity-sensitive civic parties) oraz partie wieloetniczne. Partie określane mianem monoetnicznych kierują swój apel wyborczy do jednej grupy etnicznej. Partie kandydatów mniejszościowych nastawione są na reprezentację interesów więcej niż jednej grupy etnicznej wyrażaną w biernej partycypacji wyborczej z jej list. Partie z trzeciej grupy apelują 
do szerszego niż etniczny elektoratu, traktując tamten drugoplanowo. Również rekrutują kandydatów na swoje listy spośród członków mniejszości etnicznych, do których też kierują pewne elementy swojego programu. Często są to partie lewicowe lub liberalne, otwarte na prawa mniejszości. Ostatnią kategorię zaobserwowaną przez F. Biebera stanowi partia - koalicja grup etnicznych (Bieber, 2008, s. 13).

\section{PARTIE ETNICZNE W REPUBLICE CZESKIEJ JAKO PAŃSTWIE ŚRODKOWOEUROPEJSKIM}

Na kształt współczesnych systemów partyjnych państw w Europie Środkowej i Wschodniej wpłynął bezsprzecznie okres komunizmu, w trakcie którego obserwowaliśmy między innymi zamrożenie systemu partyjnego oraz kwestii etnicznych w tych państwach. Przyjmuje się, że na fali demokratyzacji i po rozpadzie Związku Radzieckiego nastąpiła gwałtowana eskalacja nacjonalistycznych resentymentów w krajach niegdyś należących do jego strefy wpływów (Zenderowski, 2011, s. 7; Zenderowski \& Pieńkowski, 2014, s. 9). Kwestia etniczna znalazła swoje przełożenie w systemach partyjnych tych państw.

Powstanie partii etnicznej może stanowić etap instytucjonalizacji konfliktu o tym charakterze - polityzacji (Kostecki, 2011, s. 21) - i jest przejawem rozłamu socjopolitycznego centrum-peryferie. Kwestia etniczna staje się częścią polityki publicznej, wymagającą decyzji wysokiego szczebla i alokacji środków. Obserwuje się mobilizację grup etnicznych (społecznych) wokół konkurencyjnych celów. Postrzeganie nierówności jest czynnikiem, który wyzwala otwarty konflikt, przez co powstaje przestrzeń społeczna dla różnorodnych form organizacji politycznej i pojawiania się liderów politycznych. Upolitycznienie stanowi wymóg dla zdobycia poparcia społecznego, które ma utrzymać wydarzenia zachodzące W danej grupie etnicznej pod kontrolą i zapobiec wrogim działaniom wobec niej (Kostecki, 2011, s. 22). Konflikt centrum-peryferia to konflikt o ową alokację dóbr. Celem peryferyjnych ruchów jest autonomia w ramach państwa, a nawet niepodległość, na co centrum odpowiada polityką unifikacji - gospodarczej, kulturowej czy językowej, za pomocą choćby edukacji. Peryferyjność związana jest z centralizacją polityczną państwa, narzucaniem przez polityczne centrum panującej kultury i języka, jak również z nierównomiernym rozwojem gospodarczym (Lubina, 2014, ss. 26-27). Ostatni z czynników, rozumiany jako zaniedbanie zasady sprawiedliwości w dystrybucji dóbr, powoduje w głównej mierze resentymenty opisywane jako etniczne oraz pojawianie się konfliktów / rozłamów wokół dystrybucji zasobów, ale też jako sposobów na ich pozyskiwanie czy bogacenie się. Czynnik ekonomiczny jest więc rozstrzygający. Radosław Zenderowski zauważa, że „wyprzedza on czynnik polityczny, ideologiczny, a tym bardziej religijny” oraz że „[...] mechanizm ten znajduje zastosowanie w wielu innych regionach świata [...]" (Zenderowski, 2012, s. 420).

Należy stwierdzić, że upadek komunizmu sam w sobie nie był główną przyczyną polityzacji etniczności w Europie Środkowej i Wschodniej, zwłaszcza w latach 90. XX w., ale jego następstwa w postaci transformacji gospodarczej, kryzysów ekonomicznych oraz możliwość otwartego zamanifestowania niezadowolenia z tych następstw. Zjawisko upolitycznienia etniczności jest uniwersalne i obserwowane na całym świecie od lat, a jego natężenie wynika ze zmian ekonomicznych i politycznych. Nie jest zaś zjawiskiem specyficznym dla tego regionu i jego cechą charakterystyczną, nie powinien też uprawniać do stereotypowych zresztą ocen o zagłębiu porachunków plemiennych czy antyse- 
mityzmu, co słusznie zauważa R. Zenderowski (Zenderowski, 2011, s. 7; Zenderowski \& Pieńkowski, 2014, s. 10).

\subsection{Mniejszości etniczne i narodowe w Republice Czeskiej po 1989 r.}

Na początku lat 90. XX w. w Republice Czeskiej (wchodzącej jeszcze w skład Czeskiej i Słowackiej Republiki Federacyjnej (Bankowicz, 2010, s. 80) prawie 20 proc. jej obywateli deklarowało przynależność do innej niż czeska grupy etnicznej, a ponad połowę z nich - 13 proc. stanowili Morawianie. Odsetek ten zmniejszył się w ciągu następnej dekady do 3,7 proc, po czym wzrósł do 5 proc. w 2011 r. Spadł odsetek mniejszości romskiej, z 0,3 proc. w 1991 r. do prawie 0,0 w 2011 r. Agregat, w którego skład wchodzi mniejszość polska, niemiecka, węgierska i ukraińska, także zmniejszył się od 1991 do 2011 r., z 1,4 proc. do 1,2. Nie należy jednak pomijać faktu, że wraz ze spadkiem deklaracji przynależności do mniejszości etnicznych i narodowych obserwujemy w interesującej nas czasoprzestrzeni wzrost deklaracji w kategoriach Inna - od 0,2 do 2,5 proc. - oraz Nieokreślo$n a-z$ 0,2 do aż 25,3 proc. w 2011 r. Największy spadek odsetka deklaracji narodowości miał miejsce w przypadku grupy czeskiej, wynosił bowiem prawie 17 proc.

Spadki te mogą być wyjaśniane nie tylko zmniejszaniem się populacji każdej z grup etnicznych w wyniku asymilacji i odpływem części ich reprezentantów (do Innych lub Nieokreślonych), ale także zmniejszeniem zainteresowania kwestiami etniczności samych Czechów w wyniku rozwoju społeczno-gospodarczego państwa, który mógł też spowodować tendencje kosmopolityczne. Wyjaśnienie tego wątku wymaga odrębnego opracowania i pogłębienia badań.

Tabela 1. Struktura etniczna na ziemiach czeskich w latach 1991-2011

\begin{tabular}{|l|r|r|r|r|r|r|}
\hline \multirow{2}{*}{ Mniejszość } & \multicolumn{2}{|c|}{1991} & \multicolumn{2}{c|}{2001} & \multicolumn{2}{c|}{2011} \\
\cline { 2 - 7 } & $\%$ & \multicolumn{1}{c|}{ liczba } & \multicolumn{1}{c|}{$\%$} & \multicolumn{1}{c|}{ liczba } & \multicolumn{1}{c|}{$\%$} & \multicolumn{1}{c|}{ liczba } \\
\hline Czeska & 81,2 & 8363768 & 90,4 & 9249777 & 64,3 & 6711624 \\
\hline Morawska & 13,2 & 1362313 & 3,7 & 380474 & 5,0 & 521801 \\
\hline Śląska & 0,4 & 44446 & 0,1 & 10878 & 0,1 & 12214 \\
\hline Słowacka & 3,1 & 314877 & 1,9 & 193190 & 1,4 & 147152 \\
\hline Romska & 0,3 & 32903 & 0,1 & 11746 & 0,0 & 5135 \\
\hline Ukraińska & 0,1 & 8220 & 0,5 & 22112 & 0,5 & 53253 \\
\hline Rosyjska & 0,1 & 5062 & 0,1 & 12369 & 0,2 & 17872 \\
\hline Polska & 0,6 & 59383 & 0,5 & 51968 & 0,4 & 39096 \\
\hline Niemiecka & 0,5 & 48556 & 0,4 & 39106 & 0,2 & 18658 \\
\hline Węgierska & 0,2 & 19932 & 0,1 & 14672 & 0,1 & 8920 \\
\hline Inna & 0,2 & 18812 & 0,7 & 698351 & 2,5 & $257430^{2}$ \\
\hline Nieokreślona & 0,2 & 22017 & 1,7 & 172827 & 25,3 & 2642666 \\
\hline
\end{tabular}

Źródło: www.csu.cz

w tym podwójna

w tym podwójna 


\subsection{HZD-SMS - jedyna czeska licząca się partia etnoregionalna}

Ruch na Rzecz Demokracji Samorządowej - Stowarzyszenie dla Moraw i Śląska (cz. Hnutí za samosprávnou demokracii-Společnost pro Moravu a Slezsko [HSD-SMS]) jest jedyną etniczną organizacją polityczną w historii czeskiego systemu partyjnego, która miała parlamentarną reprezentację w Czeskiej Radzie Narodowej, organie ustawodawczym Republiki Czeskiej, będącej jeszcze częścią federacji ${ }^{3}$. Dlatego też jemu zostanie poświęcona znaczna część dalszego wywodu. Mimo, iż w początkowej fazie swojej działalności, równoznacznej z latami świetności, HSD-SMS stanowił ponadpartyjny ruch polityczny (Springerová, 2010, s. 49), jest traktowany jako klasyczny przejaw rozłamu centrum - peryferie, a więc konflikt Czechy - Morawy oraz jako partia etnoregionalna (Springerová, 2010, ss. 5, 32-33). Rozważanie go w kategoriach partii politycznej jest możliwe, gdyż został on zarejestrowany w ewidencji Ministerstwa Spraw Wewnętrznych 5 kwietnia 1990 r. (Springerová, 2010, s. 47). Ponadto każda partia polityczna, ruch polityczny czy też koalicja, które zarejestrowały listy wyborcze, traktuje się jako partie wyborcze w rozumieniu Czeskiego Urzędu Statystycznego ${ }^{4}$. W sensie strukturalnym HSD-SMS był początkowo ruchem politycznym, natomiast pespektywa funkcjonalna pozwalała na uznanie go za partię etnoregionalną. Późniejsze lata funkcjonowania wskazują na osiągnięcie stanu oficjalnie partii politycznej, z licznymi modyfikacjami jej nazwy i przywództwa.

\subsubsection{Tożsamość morawska}

W skład terytorium Republiki Czeskiej wchodzą trzy historyczne dzielnice: Czechy5, Morawy i Śląsk, a kombinacja ich herbów tworzy czeskie godło państwowe. Czechy stanowią 2/3 terytorium Republiki i zamieszkuje ponad połowa ludności kraju, Morawy - 28 proc. powierzchni i 30 proc. Iudności, Śląsk zaś - 7 proc. powierzchni kraju (Siwek, 2010, s. 538). Morawy położone są w południowej i wschodniej części Republiki.

Tabela 2. Republika Czeska - terytorium i ludność w ujęciu geograficznym

\begin{tabular}{|l|c|c|c|c|}
\hline \multirow{2}{*}{ Obszar } & \multicolumn{2}{|c|}{ Powierzchnia } & \multicolumn{2}{c|}{ Ludność } \\
\cline { 2 - 5 } & w tys. km² & $\%$ powierzchni & w mln & $\%$ \\
\hline Czechy & 52 & 65 & 5,5 & 55 \\
\hline Morawy & 22 & 28 & 3,1 & 30,2 \\
\hline Śląsk & 5,5 & 7 & 0,7 & 14,8 \\
\hline
\end{tabular}

Powstanie ruchu morawskiego (morawizmu) oraz późniejsze jego transformacje stanowią przejaw ochrony tożsamości etnicznej i regionalnej przez elity tej społeczności zamieszkującej obszar Moraw (Bittnerova \& Moravcová, 2009, s. 9). Tworzenie instytucji w formie partii politycznej jest więc jednym z narzędzi podtrzymywania i podkreślania odrębności Morawian i Ślązaków od reszty obywateli Republiki Czeskiej.

5 Warto odnotować, że w przeciętnej polskiej świadomości nazwa "Czechy" jawi się jako nazwa państwa, podczas gdy w rzeczywistości, zwłaszcza czeskiej, stanowi nazwę jednej z trzech jego części składowych. Dlatego też w niniejszym opracowaniu traktując o państwie czeskim, stosuję nazwę Republika Czeska, a nie - jak to często niestety ma to miejsce w wielu opracowaniach innych autorów - Czechy. Stan tej świadomości doskonale można zaobserwować w Internecie, gdzie podczas wyszukiwania hasła Republika Czeska, na pierwszym miejscu w wynikach pojawia się hasło Czechy (Wikipedia, stan na 28.04.2015 r.; „Czechy”, 2015).
} 
Tożsamość morawska nawiązuje do historii tego regionu i specyficznego położenia państwa morawskiego w XII w. względem państwa czeskiego. W 1182 r. Morawy zostały samodzielną jednostką ziemską - Marchią Morawską, a w 1197 r. potwierdzony został formalnie status tych ziem w ramach państwa Przemyślidów. Pavlína Springerová pisze, że ten system samorządu przetrwał w zasadzie do 1949 r. (Springerová, 2010, s. 38). Oznacza to, że Morawy mają wieloletnią tradycję samorządności, także o specyficznej strukturze. Kolejnymi elementami tej tożsamości jest odmienny stosunek Morawian do ruchu husyckiego, rozmiar udziału morawskiej szlachty w powstaniu państwowym w latach 1618-1620 (Springerová, 2010, s. 41). Znane są też próby podkreślania różnic językowych jeszcze w XIX w., a także przez aktywistów na Morawach, Franciszka Dobromysła Trnky i Vicence Pavla Ziaka (Springerová, 2010, s. 42).

Należy odnotować, że istnienie morawskiej tożsamości zostało oficjalnie uznane przez władze centralne, czego przejawem było umożliwienie jej deklaracji w, pierwszym po Aksamitnej Rewolucji, spisie powszechnym w 1991 r. Oprócz możliwości wyboru narodowości (niemiecka, słowacka itp.) pojawiła się również opcja wyboru przynależności morawskiej i śląskiej.

\subsubsection{Historia partii i uwarunkowania jej powstania}

O tym, że źródła powstania HSD-SMS związane są z pojawieniem się rozłamu etnoregionalnego świadczą między innymi postawy jego założycieli, widzących potrzebę organizacji interesów regionu i jego mieszkańców oraz poparcie dla ruchu.

Ruch będący przedmiotem niniejszego artykułu powstał w nawiązaniu do Stowarzyszenia na rzecz Moraw i Śląska (Společnost pro Moravu a Slezska - SMS) z 1968 r., które bez większych sukcesów promowało wówczas koncepcję równouprawnienia regionu w czechosłowackiej federacji (Springerová, 2010, s. 35). SMS powstało na fali liberalizacji w ramach Praskiej Wiosny, przy okazji debaty o przyszłej federalizacji Czechosłowacji. Jego działacze, postowie rady narodowej w południowomorawskim kraju oraz przedstawiciele morawskiej inteligencji $i^{6}$ postulowali wyrównanie asymetrycznego modelu ustroju państwa, podobnie zresztą do Słowaków. Wskazywali na dyskryminację Moraw ze strony biurokratycznego centrum w Pradze $w$ trakcie prac nad koncepcją i ustawą o federalizacji (Springerová, 2010, ss. 38-39). Propozycja stworzenia federacji, w skład której wchodzityby trzy państwa, zamiast dwóch, została odrzucona przez centrum, między innymi z powodu rozłamu w obozie promorawskim, którego połowa ostatecznie opowiedziała się za koncepcją federacji czechosłowackiej (Springerová, 2010, s. 40).

Do wznowienia działalności SMS, stłumionego inwazją sowiecką i reżimem normalizacji, doszło 30 grudnia 1989 r. W dokumencie programowym zawarto informację o celach, którymi między innymi było też zrzeszanie członków różnych partii politycznych, forów obywatelskich i innych inicjatyw obywatelskich, oraz niezrzeszonych, bez względu na światopogląd czy miejsce zamieszkania. W kwietniu 1990 r. z inicjatywy SMS odbył się zjazd założycielski HSD-SMS, po czym nastąpiła oficjalna rejestracja ruchu, którego liderem został Boleslav Bárta.

Na pojawienie się rozłamu Czechy-Morawy mogła mieć wpływ sytuacja polityczna i gospodarcza państwa. Upadek systemu komunistycznego, demokratyzacja, transformacja gospodarcza po 1989 r. sprawiły, że obywatele Czechosłowacji znaleźli się w zupełnie nowej rzeczywistości, nieznanej, a więc budzącej obawy o przyszłość, poczucie zagrożenia ich sytuacji materialnej (Fenton, 2007, s. 135). Etniczność pojawia się w odpowiednich ......

6 Na przykład rektor Uniwersytetu w Brnie - Teodor Martinec czy psycholog Boleslav Bárta. 
kontekstach, w państwach z permanentnymi zaburzeniami gospodarczymi oraz w państwach, "które doświadczyły dramatycznych zmian politycznych i niepowodzeń rządów" (Fenton, 2007, s. 138). Strach wywołany nieznanym wprowadził z kolei społeczne napięcia, między innymi etniczne, na linii Czesi-Morawianie, tym bardziej że nierównomierny rozwój gospodarczy Czech i Moraw był i nadal jest faktem. W latach 1990-1992 mógł skłaniać do resentymentów etnicznych. Zaobserwowano bowiem wyższą stopę bezrobocia w krajach morawskich niż czeskich. Dane z 1993 r. wskazują 5,28 proc. bezrobotnych w kraju południowomorawskim i 6,63 proc. w morawskośląskim, natomiast już w kraju środkowoczeskim (ze stolicą w Pradze) - 3,98 proc., czy też w kralowohradeckim - 2,587. Rzecz jasna, zróżnicowanie regionalne rozwoju gospodarczego obserwujemy nie tylko porównując odpowiednie wskaźniki w Czechach i na Morawach, różnice występowały i występują też w samych Czechach (Siwek, 2010, s. 533). Celem tej obserwacji jest zwrócenie uwagi na jej znaczenie dla pojawiania się resentymentów morawskich bądź też ich podsycania przez polityków czy media.

Kolejne wydarzenia składające się na historię partii są ściśle związane z polityką wyborczą i zostaną omówione w dalszej części artykułu. Analiza wyników wyborczych będzie bowiem łatwiejsza, kiedy towarzyszy jej aktualizowanie nazw ugrupowań wynikających z rozłamów w jej obrębie.

\subsubsection{Wyniki wyborcze}

Analizując poparcie wyborcze dla HSD-SMS, biorę pod uwage wyniki przekładające się na jego reprezentacje w Czeskiej Radzie Narodowej, a po 1993 r. w Izbie Poselskiej i Senacie. Kampania wyborcza w 1990 r. prowadzona była przez Ruch nieprofesjonalnie, chaotycznie oraz przy słabej organizacji struktur, a mimo to zakończyła się dla niego zaskakującym sukcesem (Maliř \& Marek, 2005, s. 1617; Springerová, 2010, s. 52), co potwierdza, że napięcie społeczne istniało, a nie było efektem tylko marketingu politycznego partii. HSD-SMS w pierwszych demokratycznych wyborach do Czeskiej Rady Narodowej zająt trzecie miejsce, z wynikiem 10,03 proc. $^{8}$ z 22 mandatami ${ }^{9}$, za Obywatelskim Forum i Czechosłowacką Partią Komunistyczną. Kwestia morawska (etniczno-regionalna) okazała się znacząca w okresie transformacji systemowej i gospodarczej dla Czechów. Z drugiej jednak strony, HSD-SMS mógł stanowić alternatywę dla niezdecydowanych morawskich wyborców (Malír \& Marek, 2005, s. 1617), gdzie Ruch osiągnął poparcie 27,25 proc. W województwie (kraju) południowomorawskim i 23,95 proc. W północnomorawskim ${ }^{10}$, nieodnotowane już w takiej skali w pozostałych częściach Republiki. W marcu 1991 r. doszło do rozłamu w klubie parlamentarnym HSD-SMS na forum Zgromadzenia Federalnego, a w maju tego samego roku zmarł przywódca Ruchu, B. Bárta.

Wybory w 1992 r., kolejne w realiach demokratycznych i ostatnie w ramach federacji, zakończyły się dla HSD-SMS mniejszym sukcesem niż 2 lata wcześniej. Ruch otrzymał prawie o połowę mniejsze poparcie, ledwo przekraczając próg wyborczy z 5,87 proc. ${ }^{11}$ i 14 mandatami ${ }^{12}$, w województwach południowomorawskim i północnomorawskim listach HSD-SMS znaleźli się rónież kandydaci innych partii, np. Morawskiej Partii Narodowej (Moravská narodní strana - MNS), Demokratycznej Partii Pracy (Demokratická Strana Práce) czy Ruchu Kobiet (Hnutí Žen), którzy także stali się beneficjentami głosowania - 2 mandaty przypadły MNS, a 1 - Demokratycznej Partii Pracy.
} 
16,19 proc. i 12,60 proc. ${ }^{13}$ Po tych wyborach doszło do poważnego zaostrzenia podziałów w Ruchu na skrzydło centrowe, otwarte na inne niż regionalny segmenty elektoratu czeskiego, oraz na radykalnie morawistyczne, na co miała wpływ niewątpliwie zmiana przywództwa w ruchu na skutek śmierci B. Bárty w 1991 r. Nowym liderem HSD-SMS został Jan Kryčer (Malír \& Marek, 2005, ss. 1620-1621), którego działalność partyjna zaowocowała szerokim spektrum skutków. Między innymi w 1994 r. liberalna część zadecydowała o transformacji z "niejasnego ruchu” w "centrową partię o morawskim rdzeniu”. Powstały Czeskomorawska Partia Centrum (Českomoravská Strana Středu - ČMSS), której przewodził wspomniany J. Kryčer, oraz Ruch Samorządnych Moraw i Śląska (Hnutí Samosprávné Moravy a Slezska - HSMS) z liderem Janem Smejkalem. Doszło więc do otwartego podziału na część brneńską, wyraźnie podkreślającą tożsamość morawską, ale odcinającą się jednocześnie od morawskich nacjonalistów z MNS, oraz na liberałów z północy. Ci ostatni zarejestrowali również organizacje o nazwach nawiązujących do swoich korzeni, a więc Ruch na rzecz Demokracji Samorządowej - Stowarzyszenie na rzecz Moraw i Śląska - (Hnutí za samosprávnou demokracii-Společnost pro Moravu a Slezsko (HSD-SMS) oraz Ruch na rzecz Demokracji Samorządowej Moraw i Śląska (Hnutí za samosprávnou demokracii Moravy a Slezska), w celu zablokowania nazw i prób wykorzystywania przez konkurencyjne ugrupowania morawistyczne (Malír \& Marek, 2005, s. 1622).

Wybory na przełomie maja i czerwca 1996 r. oficjalnie kończą okres relewancji politycznej partii morawskich. Żadnemu z ugrupowań nie udało się przekroczyć nawet 1 proc. poparcia w skali całego kraju ${ }^{14}$. W listopadzie tego roku odbyły się też pierwsze wybory do Senatu Republiki Czeskiej. Porażka sprzed kilku miesięcy spowodowała w środowisku morawistów złagodzenie konfrontacyjnego dotąd stylu współpracy między poszczególnymi skrzydłami i ich reprezentantami. Doszło do integracji tych ugrupowań, czego efektem było powstanie Koalicji Morawskośląskiej (Moravskoslezská Koalice - MSK). Zjednoczenie radykalnych ugrupowań morawskich z morawskimi centrystami nie odniosło zakładanych skutków. Żaden z kandydatów koalicji nie dostał się do drugiej tury wyborów do Senatu Republiki Czeskiej (Springerová, 2010, s. 151).

Podobne efekty rywalizacji wyborczej obserwujemy w kolejnych wyborach, w latach 1998-2014 ${ }^{15}$. W 2005 r. doszło do zjednoczenia części ugrupowań morawskich i utworzenia jednego podmiotu pod nazwą Morawianie (Moravané), który jednoznacznie nawiązuje do HSD-SMS jak i do Morawskiej Partii Narodowej. Jej obecnym liderem jest Ondřej Hý$\operatorname{sek}^{16}$, a partia konsekwentnie kładzie nacisk na rozwój samorządności Moraw" ${ }^{17}$.

\subsubsection{Program polityczny}

W tej części artykułu zaprezentowane zostaną elementy programowe morawskich ruchów i partii politycznych, składające się na ich apel wyborczy w latach 1990-1996.

Ruch politycznego morawizmu nie był jednolity. Można wyodrębnić w nim trzy nurty programowe: liberalny, konserwatywny (umiarkowany) i radykalny, których bazę stanowi morawska tożsamość etniczna. Początkowo współwystępowały nawet $w$ ramach tych samych organizacji, dzieląc jej zwolenników oraz stwarzając efekt niekonsekwencji. Po

16 http://www.moravane.cz/o-nas/historie-strany (31.05.2015) („Moravané - Politická strana - Historie strany", b.d.).

17 http://www.parlamentnilisty.cz/profily/Mgr-Ondrej-Hysek-Ph-D-16044 (31.05.2015) („Mgr. Ondřej Hýsek Ph.D. | Parlamentní Listy | ParlamentniListy.cz - politika ze všech stran", b.d.)
} 
1991 r. nastąpił jednak proces krystalizacji nurtów, który zakończył się wytworzeniem kilku partii morawskich, wyraźnie podkreślających wzajemne odrębności, doprowadzając w ostateczności do zaniku politycznego wpływu tych ugrupowań w polityce publicznej państwa.

Wszystkie nurty morawizmu łączył postulat samorządności regionu morawsko-śląskiego, jednak od stopnia samorządności zależał fakt przyporządkowania danego ugrupowania do poszczególnych nurtów. Zauważamy więc praktyczne zastosowanie typologii partii etnoregionalnych w ramach jednego państwa i w obrębie tej samej grupy etnicznej, którą proponowali J. T. Ishiyama i M. Breuning, wskazując trzy typy ugrupowań etnicznych: umiarkowanego protekcjonizmu, partie autonomistyczne (narodowo-federalistyczne) oraz separatystyczne.

Po ogłoszeniu renesansu Stowarzyszenia na Rzecz Moraw i Śląska w 1989 r. od jego aktywistów odciął się niezwłocznie Miroslav Richter, odmawiając jakiejkolwiek współpracy z ludźmi mającymi powiązania z przeszłością, a więc z komunistami sprzed 1989 r. jak i tymi, którzy z Komunistycznej Partii Czechosłowackiej zostali po 1968 r. wydaleni. Wspomniany B. Barta prezentował odwrotną postawę - miał wśród potępianych przez Richtera ludzi przyjaciół - chciał wykorzystać polityczne kontakty z byłymi "sześćdziesięcioośmiakami", którzy po 1989 r. wracali do najwyższych funkcji (Springerová, 2010, ss. 45-46). Tak powstało środowisko Morawskiego Ruchu Obywatelskiego (Moravské Občanské Hnutí - MOH), które oprócz antykomunizmu, postulowało pod hasłem "Demokracja dla wszystkich", osiągnięcie autonomii na wzór państwa, odnowę Moraw w jej historycznych granicach, utworzenie lokalnej izby deputowanych, rządu morawskiego, ekonomiczną niezależność Moraw, modernizacje dróg i kolei, powstanie banku morawskiego (Springerová, 2010, s. 54). MOH reprezentował konserwatywne (umiarkowane) skrzydło ruchu morawskiego i stanowił przykład autonomistycznego typu partii etnoregionalnej. Morawianie według poglądów M. Richtera stanowili gałąź narodu czeskiego, natomiast część działaczy MOH miała inne zdanie, stawiając etniczność morawską na równi z narodowością (np. czeską). W konsekwencji zostali oni usunięci z szeregów MOH i we wrześniu 1990 r. założyli Morawską Partię Narodową (Moravská narodní strana - MNS), której przewodniczącym został ekonomista Miloš Skočovský. Członkowie MNS uważali się za następców Narodowej Partii Morawskiej, działającej w latach 1861-1911 pod przewodnictwem Aloise‘a Pražaka (Springerová, 2010, s. 68). MNS postulowała uznanie narodu morawskiego jako komponentu państwotwórczego, utworzenie republiki morawskiej, uznanie i gwarancję historycznych granic morawskich, program gospodarczy dla regionów morawskich, uwzględniający ich specyfikę (Springerová, 2010, s. 69). MNS prezentowała radykalny odłam morawizmu i była przykładem partii separatystycznej w rozumieniu typologii badaczy zachodnich.

HSD-SMS i jego kolejne przemiany stanowią przykład ugrupowania, które ewoluowało z poziomu partii konserwatywnej (autonomistycznej) do partii liberalnego morawizmu (umiarkowanego protekcjonizmu). W pierwszym dokumencie programowym - Deklaracji Morawskośląskiej z kwietnia 1990 r. - członkowie HSD-SMS proponowali rozwiązanie kwestii ustroju terytorialnego na poszczególnych poziomach ustanowieniem autonomii ziem z władzami w postaci lokalnych izb deputowanych / komitetów. Ruch postulował też autonomię gospodarczą naturalnych geomorfologicznych całości, a więc Czech, Moraw ze Śląskiem i Słowacją, zjednoczonych w ramach trójfederacji czechosłowackiej. Jego członkowie podkreślali: „Nie jesteśmy separatystami, ale zasługujemy na jedność, która nie poniża i nie dyskryminuje". Innymi słowy, HSD-SMS domagało się równoupra- 
wnienia Moraw i uznania ich za trzecią republikę wchodzącą w skład Czechosłowacji (Springerová, 2010, s. 48).

W 1993 r. Ruch zbliżył się ideologicznie do podmiotów centrowych. Zrezygnował z morawskiego nacjonalizmu i oparł się na polityce „środka". Po zmianie nazwy profil HSDMS przejawiał się już jako autonomiczny podmiot, niedopuszczający kandydatów innych partii i ruchów do swoich list (Springerová, 2010, s. 121). Po transformacji w partię polityczną o nazwie Czeskomorawska Partia Centrum jej działacze, starając się o konsolidację ogólnokrajową, otworzyli się jeszcze bardziej na szersze spektrum problemów niż regionalne. CMSS popierała wstąpienie Republiki Czeskiej do Unii Europejskiej i NATO. Zajmowała stanowiska wobec aktualnych i długofalowych problemów państwa, nawołując do reform gospodarczych i krytykując dotychczasowe rozwiązania (Springerová, 2010, s. 125).

\subsection{Coexistentia - Wspólnota jako próba partii wieloetnicznej}

Spośród ugrupowań etnicznych (narodowościowych) Coexistentia-Wspólnota (Coexistentia-Soužití - COEX) stanowi drugą po partiach morawskich organizację polityczną mniejszości w Republice Czeskiej, która osiągnęła relatywny sukces. W początkowym etapie jej działalności miała pewne cechy partii wieloetnicznej. Zmiany, których doświadczyła po 1992 r., ograniczyły baze społeczną COEX do reprezentowania interesów mniejszości, głównie polskiej. Transformację tę można opisać w skrócie jako przemianę wieloetnicznej partii typu niepodległościowego w partię monoetniczną umiarkowanego protekcjonizmu. Główną przyczyną tego przeobrażenia się była zmiana polityczno-ustrojowa z 1993 r. Formalnie COEX nadal pozostaje ruchem politycznym, spełniając jednak funkcje partii politycznej. Tak też jest rozpatrywany przez czeskich politologów.

\subsubsection{Historia partii i uwarunkowania jej powstania}

W historii COEX można wyodrębnić dwa etapy, których wyznacznikiem jest rozpad Czechosłowacji na przełomie lat 1992-1993. W początkowym etapie funkcjonowania ruchu stanowił on część relewantnego federalnego podmiotu, posiadającego swoje zaplecze społeczne w obu republikach czechosłowackiej federacji, dominując jednak w słowackiej. Drugi etap obserwujemy od roku 1993 r., kiedy Coexistentia straciła na znaczeniu, z pozycji ogólnokrajowej partii politycznej stała się podmiotem marginalnym o regionalnym zasięgu działania (Kopeček, 2003, s. 17), ograniczając się do czeskiego Śląska Cieszyńskiego.

Głównymi inicjatorami założenia ruchu byli działacze sekcji polskiej Obywatelskiego Forum, którzy reprezentowali jej radykalne skrzydło: Stanisław Gawlik, Edward Macura i poseł Czeskiej Rady Narodowej, Władysław Niedoba. Ten ostatni w grudniu 1989 r. na forum parlamentarnym skrytykował „wynarodowienie polskiej mniejszości poprzez dyskryminację językową i edukacyjną, przemieszczenie polskiej inteligencji w głąb kraju, zapobieganie jej kontaktom z Polską" (Kopeček, 2003, s. 197). Podobne poglądy mieli liderzy mniejszości węgierskiej, w wyniku czego doszło w 1990 r. do nawiązania współpracy przy tworzeniu ugrupowania ogólnokrajowego, reprezentującego interesy mniejszości narodowych w Czechosłowacji. 31 marca tego roku na kongresie inaugurującym partię w Bratysławie ustalono, że przewodniczącym partii zostanie węgierski dysydent Miklos Duray, a zastępcą Stanisław Gawlik. Komponent węgierski okazał się kluczowym dla partii pod względem liczebności i spójności, a poparcie ze strony pozostałych mniejszości, ze względu na ich niewielką populację, było drugorzędne (Kopeček, 2003, s. 17). 
Na ogólnokrajowym zjeździe COEX 7 grudnia 1992 r. w Czeskim Cieszynie podjęto decyzję o zakończeniu wspólnej działalności partii oraz o rozpoczęciu nowego etapu jako dwie odrębne organizacje w nowo powstałych republikach. Decyzję tę potwierdził w styczniu 1993 r. kongres partyjny w Komarnie. Polska odnoga próbowała jeszcze utrzymać formalnie wielonarodowy charakter partii. Kongres COEX w Ostrawie z 15 maja 1993 r. wybrał na przewodniczącego S. Gawlika oraz uchwalił utworzenie narodowych sekcji: polskiej, węgierskiej i ukraińsko-rusińskiej. W praktyce jednak, z wyjątkiem polskiego ogniwa, inne nie przejawiały prawie żadnej aktywności, redukując liczebność swoich członków do minimum. Ich znaczenie ograniczone było do poziomu jedynie symbolicznego. Pod koniec lat 90. partii groziło całkowite zakończenie działalności z powodu powtarzającego się nierespektowania obowiązków wynikających z ustawy obligującej do dokumentowania jej gospodarki pieniężnej. W maju 2001 r. doszło nawet do tymczasowego (rocznego) zawieszenia działalności partii przez orzeczenie Sądu Najwyższego. Zanim jeszcze to nastąpiło, przywództwo objął W. Niedoba (Kopeček, 2003, s. 17).

Dopiero w XXI w. można zaobserwować wyraźniejszy przejaw wieloetniczności partii COEX, albowiem funkcję przewodniczącego od 2005 r. zaczęli obejmować ponownie węgierscy działacze, László Attila Kocsis, a następnie Sándor Pállfy ${ }^{18}$. Po śmierci ostatniego z nich, w 2014 r. stanowisko lidera powróciło do członka polskiej sekcji ruchu - Józefa Przywary ${ }^{19}$.

\subsubsection{Wyniki wyborcze}

Coexistentia-Wspólnota w pierwszym etapie swojej działalności nie kandydowała w wyborach do Czeskiej Rady Narodowej, kierując swoje siły na obszar słowacki. W 1996 r. zgłosiła udział w rywalizacji wyborczej do Izby Poselskiej wraz z ruchem Niezawisłych, na którego listach znalazły się nazwiska działaczy COEX. Żaden z kandydatów Wspólnoty nie uzyskał jednak mandatu. W kolejnych wyborach w 1998 r. partia nie wzięła udziału na skutek ogłoszonego przez nią bojkotu tej formy wyłaniania reprezentacji politycznej, spowodowanego brakiem gwarancji materiałów wyborczych w języku polskim. Cztery lata później Coexistentia ogłosiła współprace koalicyjną z Partią Wsi (Strana Venkova), na której listach, podobnie jak w 1996 r., znaleźli się kandydaci COEX. Wybory te również zakończyły się porażką i brakiem reprezentacji ruchu w Izbie Poselskiej (Kopeček, 2003, s. 17). W 2006 r. ruch nie zarejestrowat list w wyborach do izby niższej ${ }^{20}$, podobnie też zachowat się w kolejnych, w 2010 i 2013 r. ${ }^{21}$

Mimo braku sukcesów wyborczych na poziomie centralnym ruch nie zaprzestawał politycznej działalności i skupił się na aktywności lokalnej. To właśnie sukcesy wyborcze w regionie Śląska Cieszyńskiego stanowiły mocną stronę Coexistentii i nie pozwoliły jej na całkowite zaprzestanie działalności. W 1990 r. ruch obsadził 19 mandatów w jesiennych wyborach do władz gminnych. Cztery lata później uzyskał już 42 mandaty samorządowe, a w 1998 r. - 43. W 2002 r. COEX obsadzał 40 stanowisk (Kopeček, 2003, s. 195). W wyborach w październiku 2006 r. kandydaci ruchu uzyskali razem 38 mandatów w gminach

18 http://www.coexistentia.cz/pl/inform.htm (30.05.2015) („XIII Kongres Ruchu Politycznego COEXISTENTIA“, b.d.).

19 http://www.glosludu.cz/index.php?h=133404769951155512\&m=133404769951155512\&b=14321092993 9\#b143210929939 (30.05.2015) („Głos Ludu: Gazeta Polaków w Republice Czeskiej”, b.d.).

20 http://www.volby.cz/pls/ps2006/ps52?xjazyk=CZ (30.05.2015) („Volby.cz - Český statistický úřad | čsú“, b.d.).

21 http://www.volby.cz/pls/ps2010/ps82?xjazyk=CZ (30.05.2015) („Volby.cz - Český statistický úřad | Čsú", b.d.). 
Frydek Mistek i Karwina22, a w 2010 r. - 33 mandaty. W 2014 r. COEX reprezentowało 30 przedstawicieli w wyżej wymienionych gminach na Śląsku Cieszyńskim²3. Zauważamy więc stopniowy spadek liczby mandatów od roku 1998 r.

Tabela 3. Mandaty przedstawicieli gmin uzyskane przez kandydatów COEX

\begin{tabular}{|c|c|}
\hline Data wyborów & Liczba mandatów \\
\hline 1990 & 19 \\
\hline 1994 & 42 \\
\hline 1998 & 43 \\
\hline 2002 & 40 \\
\hline 2006 & 38 \\
\hline 2010 & 33 \\
\hline 2014 & 30 \\
\hline
\end{tabular}

Źródło: opracowanie własne na podstawie www.volby.cz

\subsubsection{Program polityczny}

Program polityczny ruchu Coexistentia ewoluował od radyklanego do umiarkowanego w kwestiach samostanowienia narodu i stosunku mniejszości do państwa przyjmującego. Uczestnicy kongresu inauguracyjnego w marcu 1990 r. obrali za cel forsowanie i ochronę kolektywnych praw mniejszości narodowych oraz jako poboczne - działania na rzecz współżycia narodów: polskiego, węgierskiego, słowackiego, niemieckiego, rusińsko-ukraińskiego, czeskiego i żydowskiego oraz szczególne wsparcie Romów w ich wysiłkach na rzecz osiągnięcia równouprawnienia (Kopeček, 2003, s. 191). Cele wynikające z programu w pierwszym etapie działalności ruchu zawierały również odrzucenie i potępienie państwa narodowego, zagrażającego mniejszościom etnicznym w zagwarantowaniu im ochrony przed dominacją większości.

Po przemianach ustrojowych związanych z rozpadem federacji program ten uległ pewnym modyfikacjom. Otóż zrezygnowano z postulatów antysystemowych, pozostawiono zaś nacisk na ochronę praw mniejszości rozumianą jako: prawo do używania rodzimego języka w kontaktach urzędowych, prawo do nauki w tym języku, prawo do rozpowszechniania informacji w języku mniejszości, prawo do rozwoju kultury i tradycji mniejszości itp. Ograniczenie radykalizmu było prawdopodobnie wynikiem uświadomienia sobie pozycji mniejszości polskiej w niemal narodowo homogenicznej Republice Czeskiej. Zniknęły więc sformułowania zdecydowanie odrzucające państwo narodowe, w miejsce czego pojawił się nacisk na rozwój społeczeństwa obywatelskiego (Kopeček, 2003, s. 10). Po aktualizacji w roku 2013 cele programowe nie uległy znaczącym zmianom²4.

22 http://www.volby.cz/pls/kv2006/kv22?xjazyk=CZ\&xid=1\&xv=8 (31.05.2015) („Volby.cz - Český statistický úřad | ČSú“", b.d.).

23 http://www.volby.cz/pls/kv2014/kv22?xjazyk=CZ\&xid=1\&xv=8\#8100 (31.05.2015) („Volby.cz - Český statistický úřad I Čsú", b.d.).

24 Wśród postulatów ekonomicznych i socjalnych COEX wymienia: - oszczędne dysponowanie źródłami przyrody i energii; - zapewnienie podstawowego zasięgu komunikacyjnego i podniesienie udziału trakcji elektrycznej w transporcie kolejowym; - dokończenie kolejowych, wodnych i drogowych połaczeń Republiki Czeskiej, przede wszystkim przemysłowej aglomeracji ostrawsko-karwińskiej z Europą; - odrzucenie prywatyzacji za wszelką cenę przewoźników ogólnopaństwowych; - reforma ustaw podatkowych i uproszczenie warunków dla inicjatywy prywatnej, przede wszystkim dla małych i średnich firm; - wejście do strefy euro i uelastycznienie rynku pracy; - wprowadzenie indywidualnych umów ubezpieczeniowych zawartych między obywatelem i ubezpieczalnią w ubezpieczeniu zdrowotnym. 


\subsection{Partie romskie}

Najbardziej znaną partią romską w Republice Czeskiej była Romska Inicjatywa Obywatelska w Republice Czeskiej (Romská občanská iniciativa $\check{C} R$ - ROI). Partia powstała pod koniec 1989 r., a jej rejestracja przypadła na marzec 1990 r. Początkowo ROI działała w ramach Obywatelskiego Forum, dzięki czemu udało jej się wprowadzić w pierwszych wolnych wyborach w 1990 r. swoich przedstawicieli do Czeskiej Rady Narodowej (Fiala, Mareš, \& Strmiska, 2003, s. 78). Byli to: Dezider Balog ${ }^{25}$, Zdeněk Guži ${ }^{26}$, Ondřej Giňa ${ }^{27}$, Karel Holomek $^{28}$ i Milan Tatár ${ }^{29}$. Po rozpadzie OF, ROI zgłosiła samodzielny udział w wyborach w 1992 r., osiągając bardzo słabe wyniki wyborcze - otrzymała tylko 0,26 proc. głosów. Wtedy też ROI zaczęła efektywniej działać jako grupa interesu niż jako partia polityczna, na poziomach lokalnym, krajowym i międzynarodowym. W kolejnych wyborach, w 1996 i w 1998 r., już nie startowała. W 2002 r. zgłosiła listę tylko w województwie morawskośląskim, a wynik był również słaby - 0,09 proc., w skali ogólnokrajowej 0,01 proc.

$\mathrm{ROI}$ nie stanowiła jedynego reprezentanta interesów mniejszości romskiej w Republice. Inne podmioty, o równie marginalnym poparciu bądź jeszcze niższym, stopniowo zanikały lub zawiesiły działalność. Wśród nich można wymienić Ruch Zaangażowanych Romów (Hnutí angažovaných Romů), Romski Kongres Narodowy (Romský národní kongres), Partię Obywateli Narodowości Romskiej (Strana občanů romské národnosti), Czeskie Narodowości i Ruchy Romskie w Republice Czeskiej (České národnostní a romské hnutí v ČR), Chrześcijańsko-Demokratyczną Partię Romów (Křestanska a demokratickou stranu Romů), Partię Obywateli Narodowości Romskiej Kraju Północnoczeskiego (Strana občanů romské národnosti Severočeského kraje) (Fiala i in., 2003, s. 78).

ROI deklarowała ochronę każdego członka mniejszości romskiej przed bezpośrednią i pośrednią dyskryminacją przez pojedyncze osoby, grupy i wspólnoty, a także organy państwowe (Malî́ \& Marek, 2005, s. 1647). Partia zakończyła swoją działalność w 2009 r., po wyroku Najwyższego Sądu Administracyjnego, który zdecydował o jej rozwiązaniu wskutek powtarzających się braków w przedkładaniu czeskiej Izbie Poselskiej rocznych sprawozdań finansowych (za 2004, 2005 i 2006 r.) ${ }^{30}$. Romska Inicjatywa Obywatelska była przykładem partii monoetnicznej umiarkowanego protekcjonizmu. Niedostateczna liczebność elektoratu oraz życie w diasporze mniejszości romskiej stanowią główne przyczyny braku sukcesów wyborczych partii romskich.

\subsection{Specyfika partii etnicznych w Republice Czeskiej. Podsumowanie}

Podsumowując dotychczasowe rozważania, należy wskazać na kilka istotnych faktów. Po pierwsze, w Republice Czeskiej bezsprzecznie mieliśmy do czynienia z podmiotami, które możemy określić mianem partii etnicznych. Są to instytucje, które zaczynały od ruchu spo-

25 http://www.volby.cz/pls/cnr1990/u391?xvstrana=07\&xkraj=34\&xvyb=0\&xtr=1 (29.04.2015) („Volby.cz - Český statistický úrad | ČSú", b.d.).

26 http://www.volby.cz/pls/cnr1990/u391?xvstrana=07\&xkraj=36\&xvyb=0\&xtr=1 (29.04.2015) („Volby.cz - Český statistický úrad | Čsú", b.d.).

27 http://www.volby.cz/pls/cnr1990/u391?xvstrana=07\&xkraj=32\&xvyb=0\&xtr=1 (29.04.2015) („Volby.cz - Český statistický úrad I Čsú", b.d.).

28 http://www.volby.cz/pls/cnr1990/u391?xvstrana=07\&xkraj=37\&xvyb=0\&xtr=1 (29.04.2015) („Volby.cz - Český statistický úřad | Čsú”, b.d.).

29 http://www.volby.cz/pls/cnr1990/u391?xvstrana=07\&xkraj=35\&xvyb=0\&xtr=1 (29.04.2015) („Volby.cz - Český statistický úrad | Čsú”, b.d.).

30 Rozsudek Nejvyššiho správního soudu ze dne 24. června 2009, sp. zn. Pst 20/2008 (2009); http://www. nssoud.cz/files/SOUDNI_VYKON/2008/0020_0Pst_0800039A_prevedeno.pdf (29.04.2015). 
łeczno-politycznego, by przekształcić się w partię polityczną, czego przykładem jest Ruch na Rzecz Demokracji Samorządowej - Stowarzyszenie dla Moraw i Śląska, obecnie działający jako partia Morawianie. Są to również podmioty, które nadal deklarują swój status ruchu (COEX).

Po drugie, partie te rozpoczęły swoją działalność po rozpadzie Obywatelskiego Forum, które umożliwiło im inaugurację aktywności na szczeblu parlamentarnym. U części z nich było to jedną z przyczyn ich relewancji politycznej na początku lat 90.

Po trzecie, stymulatorami sukcesów były skutki transformacji ustrojowej i gospodarczej po upadku komunizmu w Czechosłowacji, które przyczyniły się do powstania napięć i ujawnienia różnic między poszczególnymi częściami kraju i jego obywatelami. W późniejszym okresie, w miare konsolidacji demokracji w Republice Czeskiej znaczenie partii etnicznych zmalało i obecnie jest ograniczone do działalności politycznej na szczeblach lokalnych lub jako grupy interesu w ramach społeczeństwa obywatelskiego. Podział etnopolityczny zanikał, przyczyniając się do spadku poparcia dla ugrupowań narodowościowych.

Po czwarte, poszczególne ruchy etniczne, i środowiska stanowiące ich zaplecze, były niejednorodnymi konglomeratami, często ze sobą rywalizującymi odłamami radykalnym i umiarkowanym, czy postkomunistycznym i antykomunistycznym. Konflikty wewnętrzne utrudniały, o ile nie uniemożliwiały ogólnokrajowy sukces dążeń politycznych poszczególnych mniejszości, zwłaszcza że ich elektoraty były liczebnie ograniczone. Mnogie pojawianie się partii morawskich, powodujące zamieszanie w samych ruchu nawet na poziomie nazewnictwa, stanowi znakomitą egzemplifikację tego zjawiska.

Po piąte, należy wskazać na elementy decydujące o specyfice partii etnicznych w Republice Czeskiej. Mieliśmy do czynienia z partiami zarówno etnoregionalnymi (ugrupowania morawistyczne), jak i z partią mniejszości narodowej (COEX), a także multietnicznej (COEX) oraz partią mniejszości etnicznej (ROI), które prezentowały różne typy tychże ugrupowań, od radykalnych po umiarkowanie protekcjonistyczne. Warto też zauważyć, że w przypadku ruchu morawskiego i Coexistentii-Wspólnoty, ich elektoraty łatwo wskazać geograficznie, pochodziły bowiem z kraju morawskośląskiego. To właśnie mieszkańcy Moraw i Śląska Cieszyńskiego stanowi(ą)li zaplecze społeczne i wyborcze partii etnicznych w Republice Czeskiej. To oni zdecydowali o sukcesie Ruchu na Rzecz Demokracji Samorządowej, który swego czasu był trzecią siłą w Czeskiej Radzie Narodowej. Interesujący wydaje się przypadek COEX, którego znaczenie przed 1993 r. jako partii o zasiegu federalnym zostało zredukowane do roli partii lokalnej, cieszącej się poparciem jedynie w dwóch gminach na tzw. Zaolziu.

\section{BIBLIOGRAFIA}

Babiński, G. (1998). Metodologiczne problemy badań etnicznych. Kraków: Nomos.

Bankowicz, M. (2010). Transformacje konstytucyjnych systemów władzy państwowej w Europie Środkowej i Wschodniej. Kraków: Wydawnictwo Uniwersytetu Jagiellońskiego.

Bieber, F. (2008). Introduction: Minority participation and political parties. W Political parties and minority participation (ss. 5-31). Pobrano 2 czerwca 2017, z http://www.fes. org.mk/index.php?option=com_wrapper\&view=wrapper\&ltemid=61\&lang=en 
Bitnerova, D., \& Moravcová, M. (2009). Etnické komunity: Elity. Instituce. Stát. Univerzita Praha: Karlova v Praze.

Chandra, K., \& Metz, D. (2002). A new cross-national database on ethnic parties. Paper presented at the Annual Meeting of the Midwestern Political Science Association, Chicago. Pobrano 2 czerwca 2017, z http://www.yale.edu/macmillan/ocvprogram/ licep/5/chandra-metz/chandra-metz.pdf

Czechy. (2015, kwiecień 28). W Wikipedia, wolna encyklopedia. Pobrano 28 kwietnia 2015, z https://pl.wikipedia.org/w/index.php?title=Czechy\&oldid=49836289

Czwarty raport dotyczący sytuacji mniejszości narodowych i etnicznych oraz języka regionalnego w Rzeczypospolitej Polskiej. (2013). Warszawa.

De Winter, L., \& Türsan, H. (2003). Regionalist parties in Western Europe. New York: Taylor \& Francis. https://doi.org/10.4324/9780203169391

Fenton, S. (2007). Etniczność, Warszawa: Wydawnictwo Sic!.

Fiala, P., Mareš, M., \& Strmiska, M. (2003). Organizace etnických menšin a prosazování jejich zájmů. Sociální Studia, 9, 65-85.

Głos Ludu: Gazeta Polaków w Republice Czeskiej. (b.d.). Pobrano 30 maja 2015, z www.glosludu.cz/index.php?h=133404769951155512\&m=133404769951155512\&b= 143210929939

Herbut, R. (2002). Teoria i praktyka funkcjonowania partii politycznych. Wrocław: Wydawnictwo Uniwersytetu Wrocławskiego.

Horovitz, D. L. (1985). Ethnic groups in conflict. Berkeley: University of California Press.

Ishiyama, J. (2001). Ethnopolitical parties and democratic consolidation in postcommunist Eastern Europe. Nationalism \& Ethnic Politics, 7(3), 25-45. https://doi. org/10.1080/13537110108428636

Ishiyama, J., \& Breuning, M. (2011). What is in a name?: Ethnic party identity and democratic development in post-communist politics. Party Politics, 17(2), 223-241. https:// doi.org/10.1177/1354068810391157

Kopeček, L. (2003). Coexistentia-Soužití a politická reprezentace polské menšiny na Těšínsku. Středoevropské politické studie, 5(2-3).

Koss-Goryszewska, M. (2010). Polska polityka antydyskryminacyjna wobec mniejszości narodowych, etnicznych i rasowych w świetle prawa Unii Europejskiej. Warszawa: Instytut Spraw Publicznych.

Kostecki, W. (2011). Zaawansowane zapobieganie konfliktom. Warszawa: Oficyna Wydawnicza ASPRA-JR.

Kowalczyk, K., \& Tomczak, Ł. (2007). Czechy. Polska. Ukraina: Partie i systemy partyjne: Stan i perspektywy. Toruń: Wydawnictwo Adam Marszałek.

Lipset, S. M., \& Rokkan, S. (1967). Party systems and voters; cross-national perspectives. New York: Free Press.

Lubina, M. (2014). Birma: Centrum kontra peryferie: Kwestia etniczna we wspótczesnej Birmie (1948-2013). Kraków: Wydawnictwo Kontekst.

Malír, J., \& Marek, P. (2005). Politické strany: Vývoj politických stran a hnutí v českých zamích a československu 1861-2004. Brno: Doplněk.

Mareš, M. (2003). Etnické a regionální subjekty ve stranickém systému České republiky. Středoevropské politické studie, 5(2-3). Pobrano 2 czerwca 2017, z http://www.cepsr. com/

Mgr. Ondřej Hýsek, Ph.D. | Parlamentní Listy | ParlamentniListy.cz - politika ze všech stran. (b.d.). Pobrano 31 maja 2015, z http://www.parlamentnilisty.cz/profily/Mgr-Ondrej-Hysek-Ph-D-16044 
Moravané - Politická strana - Historie strany. (b.d.). Pobrano 31 maja 2015, z http://www. moravane.cz/o-nas/historie-strany

Rotschild, J. (1981). Ethnopolitics, a conceptual framework. New York: Columbia University Press.

Rozsudek Nejvyššího správního soudu ze dne 24. června 2009, sp. zn. Pst 20/2008. (2009). Pobrano 29 kwietnia 2015, z http://www.nssoud.cz/files/SOUDNI_ VYKON/2008/0020_0Pst_0800039A_prevedeno.pdf

Sakson, A. (2014), Mniejszości narodowe i etniczne w Polsce i w Europie: Aspekty polityczne i społeczne. Toruń: Wydawnictwo Adam Marszałek.

Siwek, T. (2010). Podziały wewnętrzne w Republice Czeskiej. Przegląd Geograficzny, 82(4), 531-548. https://doi.org/10.7163/PrzG.2010.4.3

Springerová, P. (2010). Analýza vývoje a činnosti moravistických politických subjeků $\checkmark$ letech 1989-2005. Brno: Centrum pro demokracie a kultury.

Strmiska, M. (2003). Conceptualization and typology of European regional parties: A note on methodology. Středoevropské politické studie, 5(2-3). Pobrano 2 czerwca 2017, z http://www.cepsr.com/

Touquet, H. (2011). Multi-ethnic parties in Bosnia-Herzegovina: Naša Stranka and the paradoxes of postethnic politics. Studies in Ethnicity and Nationalism, 11(3), 451-467. https://doi.org/10.1111/j.1754-9469.2011.01134.x

Van Cott, D. L. (2005). From movements to parties in Latin America: The evolution of ethnic politics. New York: Cambridge University Press. https://doi.org/10.1017/ CBO9780511756115

Volby.cz - Český statistický úřad | Čsú. (b.d.). Pobrano z http://www.volby.cz/

Wojtas, K. (2011). Partie populistyczne w Czechach i na Słowacji. Warszawa: Scholar.

XIII Kongres Ruchu Politycznego COEXISTENTIA. (b.d.). Pobrano 30 maja 2015, z http:// www.coexistentia.cz/pl/inform.htm

Zenderowski, R. (2011). Religia a tożsamość narodowa i nacjonalizm w Europie Środkowo-Wschodniej: Między etnicyzacją religii a sakralizacją etnosu (narodu). Wrocław: Wydawnictwo Uniwersytetu Wrocławskiego.

Zenderowski, R. (2012). My już jesteśmy zjedzeni...: Rola i znaczenie prawostawia w konflikcie etnicznym w Dolinie Preszewa. Warszawa: Instytut Politologii UKSW.

Zenderowski, R., \& Pieńkowski, J. (2014). Kwestie narodowościowe w Europie Środkowo-Wschodniej. Warszawa: Dom Wydawniczy Elipsa.

Żelazny, W. (2004). Etniczność: Ład - konflikt - sprawiedliwość. Poznań: Wydawnictwo Poznańskie. 